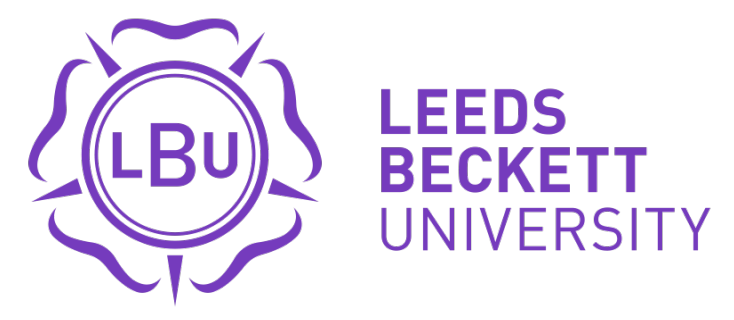

Citation:

O'Mahoney, LL and Alobaid, AM and Ajjan, RA and Birch, KM and Orsi, NM and Mappa, G and Holmes, M and Ho, P and Stavropoulos-Kalinoglou, A and Price, OJ and Campbell, MD (2020) Effects of omega-3 polyunsaturated fatty acid supplementation on parameters of glycaemic control in people with type 1 diabetes: A double-blind, randomised, placebo-controlled trial. Proceedings of the Nutrition Society, 79 (OCE3). ISSN 0029-6651 DOI: https://doi.org/10.1017/S002966512000734X

Link to Leeds Beckett Repository record:

https://eprints.leedsbeckett.ac.uk/id/eprint/7254/

Document Version:

Article (Published Version)

Published abstract

Copyright (C) The Authors 2020

The aim of the Leeds Beckett Repository is to provide open access to our research, as required by funder policies and permitted by publishers and copyright law.

The Leeds Beckett repository holds a wide range of publications, each of which has been checked for copyright and the relevant embargo period has been applied by the Research Services team.

We operate on a standard take-down policy. If you are the author or publisher of an output and you would like it removed from the repository, please contact us and we will investigate on a case-by-case basis.

Each thesis in the repository has been cleared where necessary by the author for third party copyright. If you would like a thesis to be removed from the repository or believe there is an issue with copyright, please contact us on openaccess@leedsbeckett.ac.uk and we will investigate on a case-by-case basis. 


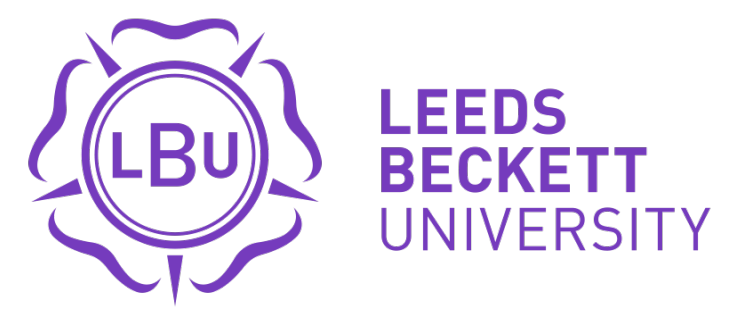

Citation:

O'Mahoney, LL and Alobaid, AM and Ajjan, RA and Birch, KM and Orsi, NM and Mappa, G and Holmes, M and Ho, P and Stavropoulos-Kalinoglou, A and Price, OJ and Campbell, MD (2020) Effects of omega-3 polyunsaturated fatty acid supplementation on parameters of glycaemic control in people with type 1 diabetes: A double-blind, randomised, placebo-controlled trial. Proceedings of the Nutrition Society. ISSN 0029-6651 DOI: https://doi.org/10.1017/S002966512000734X

Link to Leeds Beckett Repository record:

http://eprints.leedsbeckett.ac.uk/id/eprint/7254/

Document Version:

Article

The aim of the Leeds Beckett Repository is to provide open access to our research, as required by funder policies and permitted by publishers and copyright law.

The Leeds Beckett repository holds a wide range of publications, each of which has been checked for copyright and the relevant embargo period has been applied by the Research Services team.

We operate on a standard take-down policy. If you are the author or publisher of an output and you would like it removed from the repository, please contact us and we will investigate on a case-by-case basis.

Each thesis in the repository has been cleared where necessary by the author for third party copyright. If you would like a thesis to be removed from the repository or believe there is an issue with copyright, please contact us on openaccess@leedsbeckett.ac.uk and we will investigate on a case-by-case basis. 


\title{
Effects of omega-3 polyunsaturated fatty acid supplementation on parameters of glycaemic control in people with type 1 diabetes: a double-blind, randomised, placebo-controlled trial
}

\author{
L.L. O’Mahoney ${ }^{1}$, A.M. Alobaid ${ }^{2}$, R.A. Ajjan ${ }^{3}$, K.M. Birch ${ }^{4}$, N.M. Orsi ${ }^{5}$, G. Mappa ${ }^{5}$, \\ M. Holmes ${ }^{2}$, P. Ho ${ }^{2}$, A. Stavropoulos-Kalinoglou ${ }^{1}$, O.J. Price ${ }^{1}$ and M.D. Campbell ${ }^{2}$ \\ ${ }^{1}$ Carnegie School of Sport, Leeds Beckett University, Leeds, UK, \\ ${ }^{2}$ School of Food Science a Nutrition, University of Leeds, Leeds, UK, \\ ${ }^{3}$ School of Medicine, University of Leeds, Leeds, UK, \\ ${ }^{4}$ School of Biomedical Sciences, University of Leeds, Leeds, UK and \\ ${ }^{5}$ Leeds Institute of Cancer \& Pathology, St James's University Hospital, Leeds, UK
}

The effect of omega-3 polyunsaturated fatty acid (n-3 PUFA) supplementation on glycaemic control in T1D remains unclear ${ }^{(1)}$. Additionally, the effects of n-3 PUFA on postprandial glucose control in T1D are unknown. Here, we report the effect of 6-month supplementation with a daily high-dose-bolus of n-3 PUFA on parameters of glycaemic control in people with T1D.

For this double-blind, randomized, placebo-controlled trial, individuals with T1D ( $\mathrm{n}=18$; males: 14; $35 \pm 15$ years; BMI: $26.6 \pm$ $5.2 \mathrm{~kg} / \mathrm{m}^{2}$; glycated haemoglobin $\left.\left(\mathrm{HbA}_{1 \mathrm{c}}\right): 59 \pm 13 \mathrm{mmol} / \mathrm{mol}^{-1}[7.5 \pm 3.3 \%]\right)$, were randomly allocated in a 1:1 ratio to receive either $3.3 \mathrm{~g} /$ day of encapsulated n-3 PUFA or placebo (PLA) consisting of an encapsulated dose of $3.0 \mathrm{~g} /$ day corn oil for 6-months. Venous blood samples were obtained at baseline, and 6-months, to determine $\mathrm{HbA}_{1 \mathrm{c}}$, fasting plasma glucose (FPG), and postprandial glucose responses (PPGR) to a standardised mixed-meal tolerance test assessed by area under the curve over a 4-hour period. Fatty acids were measured in erythrocyte membranes by gas chromatography with n-3 PUFA index (O3I) calculated as eicosapentaenoic acid plus docosahexaenoic acid. Paired-samples $t$ tests were used to compare intragroup mean differences with statistical significance set at $p \leq 0.05$. Data are presented as mean $\pm \mathrm{SD}$.

In the n-3 PUFA group, baseline O3I increased from $4.97 \pm 0.98 \%$ to $8.24 \pm 1.52 \%$ after 6-months ( $<<0.001$ ). O3I in PLA did not change (baseline: $4.31 \pm 1.22 \%$ vs. 6-months: $4.58 \pm 1.59 \%, \mathrm{p}=0.256$ ). In the $\mathrm{n}-3$ PUFA group, the mean difference between baseline and 6-months for $\mathrm{HbA}_{\mathrm{lc}}\left(-3.89 \pm 6.05 \mathrm{mmol} / \mathrm{mol}^{-1} ; \mathrm{p}=0.090\right)$, FPG $\left(-1.04 \pm 2.82 \mathrm{mmol} / \mathrm{L}^{-1} ; \mathrm{p}=0.301\right)$, and PPGR $(-607.03 \pm 2014.63$ $\left.\mathrm{mmol} / \mathrm{L}^{-1} / \mathrm{min}^{-1} ; \mathrm{p}=0.392\right)$ did not significantly differ. Similar findings were observed in the PLA group; $\operatorname{HbA}_{1 \mathrm{c}}(\mathrm{p}=0.208), \mathrm{FPG}(\mathrm{p}=$ $0.624)$, and PPGR $(\mathrm{p}=0.966)$. Overall, no safety issues arose during administration of $n-3$ PUFA or PLA.

Supplementation with a daily high-dose-bolus of n-3 PUFA for 6-months did not modulate $\mathrm{HbA}_{1 \mathrm{c}}$, FPG, or PPGR to a mixedmeal tolerance test in people with T1D. These findings do not support the use of n-3 PUFA supplementation as an adjunct therapy in the management of T1D.

1. De Caterina R, Madonna R, Bertolotto A et al. (2007) Diabetes Care 30, 1012-1026. 